\title{
Eglantina Remport, Lady Gregory and Irish National Theatre: Art, Drama, Politics
}

Sorcha De Brún

\section{(2) OpenEdition \\ 1 Journals}

\section{Electronic version}

URL: https://journals.openedition.org/etudesirlandaises/8988

DOI: 10.4000/etudesirlandaises.8988

ISSN: 2259-8863

\section{Publisher}

Presses universitaires de Caen

\section{Printed version}

Date of publication: 24 September 2020

Number of pages: 128-130

ISSN: 0183-973X

\section{Electronic reference}

Sorcha De Brún, "Eglantina Remport, Lady Gregory and Irish National Theatre: Art, Drama, Politics", Études irlandaises [Online], 45-1 | 2020, Online since 24 September 2020, connection on 15 November 2022. URL: http://journals.openedition.org/etudesirlandaises/8988 ; DOI: https://doi.org/10.4000/ etudesirlandaises.8988

\section{(c) (i) (2)(2)}

Creative Commons - Attribution-NonCommercial-ShareAlike 4.0 International - CC BY-NC-SA 4.0 https://creativecommons.org/licenses/by-nc-sa/4.0/ 
of individual and cultural identity in the Republic. As the editor observes, the North was not part of this project, which I believe would have provided a more comprehensive outlook to the situation, along with the inclusion of studies dealing with the intersection of gender and multiculturalism in the present milieu of the island. This by no means constitutes a weakness in what is arguably a solid collection of scholarly materials that may raise abundant questions and further investigations about an extremely engaging topic.

Auxiliadora PÉREZ VIDES

\section{Eglantina Remport, Lady Gregory and Irish National Theatre: Art, Drama, Politics, Basingstoke, Palgrave Macmillan, 2018, 237 p.}

The impact of the Irish Literary Revival on the development of English and Irish language literature in Ireland and on modern literary criticism cannot be overestimated. Albeit challenging to quantify in its totality, critical appraisal of the Revival and its key figures are wide-ranging. They take the form of biographies on the life and work of individual artists and thinkers: Roy Foster's tome on W. B. Yeats (W. B. Yeats, A Life, vol. II, The Arch-Poet, Oxford, Oxford University Press, 2003); to critical studies by Philip O'Leary (The Prose Literature of the Gaelic Revival, 1881-1921, University Park, Pennsylvania State University Press, 1994); to edited collections of the short Irish language plays of the early part of the $20^{\text {th }}$ century (Drámaí Thús na hAthbheochana, edited by Éadaoin Ní Mhuircheartaigh and Nollaig Mac Congáil, Gaillimh, Arlen House, 2008). The intertwining of literature and politics is evident in the lives of many of those key figures. For example, writer, educator and revolutionary Pádraig Mac Piarais (Patrick Pearse) played an important part in the development of Irish language prose writing, while poet and senator W. B. Yeats was one of the founding members of the Abbey Theatre as was the subject of this study, Lady Augusta Gregory (née Persse) (1852-1932).

In her 2018 monograph, Eglantina Remport places Lady Gregory centre stage, taking a thematic approach to her life, work, and relationships. The study is structured into an analysis of five main strands of Gregory's social, educational and aesthetic ideals: her education in visual arts on the Grand Tours; Celtic mythology and Victorian Hellenism; education and social reform; the Pre-Raphaelite Brotherhood, the sister arts and the Irish plays; and Christianity, culture and constitutional reform. This well-written study breaks new ground in the importance it places on the multimodal symbiosis between visual and text-based arts, between political philosophy and social reform, and between Irish and English language literature. In this complex and in-depth study, Remport shows how Gregory was a driving and energetic force in the application of those ideals within the Irish Literary Revival. Although this aspect of the study has echoes of Michael Phillipson's examination of 
the relationship between arts in Painting, Language and Modernity (1985), Remport's excellent study goes further in its ambitions, in that it is unique in its examination of how Gregory's thinking was influenced by John Ruskin, whom both she and her husband Sir William Gregory knew personally. Remport describes Ruskin as "a profoundly influential social and art critic during the Victorian period" (p. 2), who held Slade professorships of fine art at Oxford University between 1870 and 1878; and again between 1883 and 1885 .

The book clearly and concisely traces the main strands of Gregory's life by providing analysis and copious primary source evidence which highlight her development as thinker, art critic, educator, dramatist, and social reformer. Remport achieves this in three ways: firstly, she examines how the diaries and notes Gregory kept on the Grand Tours of the art galleries show Gregory became increasingly more confident in her comments on art. Gregory's education in this regard informed both her thinking on art as well as her thinking on Ruskin's idea of the social importance of the arts and their relationship to reform and society. Secondly, she describes how Gregory responded to her environment, whether at Coole Park or in the pyramids of Egypt, and how her thinking was influenced by the social circles in which she moved. Thirdly, the study illuminates how Gregory engaged with the concept as well as the practice of community, whether linguistic or agricultural. This is evident in Remport's discussion of Gregory's involvement with the Home Industries, the Co-Operative Movement, and her support for the Gaelic League's revival of the Irish Language. Of special interest in that context is the account of the impact of the visual arts and various art movements such as British Hellenism and the Pre-Raphaelite Brotherhood on theatre techniques in the early years of the Abbey Theatre.

A privileged member of the Irish landed gentry, the Victorian principle of noblesse oblige or privilege entailing responsibility is referred to throughout by way of reminding the reader of the context in which the arts were understood in Victorian England. It was a principle by which many of her contemporaries lived. However, while Remport (correctly in my view) acknowledges that noblesse oblige was an important factor in Ruskin's political doctrines where the "old traditional social order of the country" (p. 65) would not be affected by reforming initiatives, she does not fall prey to the easy assumption that noblesse oblige was the sole motivating factor for Gregory's lifelong interest in the arts, education, and social reform. As was typical of her class, much of her education took place in social settings with contemporaries. But as the study reveals, Gregory had the personal characteristics and social skills to negotiate different social circles, and the Irish and English languages. For example, we read how she was educated in Irish legends with teachers Pat Mulkere and Seán Connolly, and the fruits that bore for the writing of Cuchulain of Muirthemne (1902).

The uniqueness of Lady Gregory's diaries lies in their comprising research source, personal record and educational strategy. As Lee Humphreys notes in The Qualified Self: Social Media and the Accounting of Everyday Life (Cambridge, The MIT Press, 2018, p. 2), the Edwardian and Victorian ladies' diaries were crucial 
in recording everyday life and events of house and community: "Historically, diaries, particularly those of women, chronicled everyday life activities and events of the household and community - who was born, who got sick, who died, who got married, who visited, what was planted, what was made, and so on. Women played an important role in the social chronicling of family and community events". Remport's study highlights how ideas evident in Gregory's diaries were directly influenced by Ruskin and his ideas provided a solid philosophical underpinning to her own. A critical aspect to the book is how Remport notes the transition from art connoisseur to art critic, and from thinker to philosopher. In describing this change, the study succeeds very well in comparing Gregory's development with some of the social movements in Ireland with which she was connected in a period of accelerated social growth and political change.

In addition to its legacy on the intellectual, social and cultural life of the emerging Irish nation, the Revival still resonates in the material reality of modern Ireland, from its city streetscapes to its rural landscapes. Lady Gregory and Irish National Theatre: Art, Drama, Politics succeeds brilliantly in showing how Augusta Gregory's thinking was influenced by Ruskin, but also how it was distinct from that of both Ruskin and her friend and collaborator, W. B. Yeats. Given Remport's expertise in the visual arts and the consummate ease with which she employs her encyclopaedic knowledge of art history to support her thesis, a minor quibble might be that the monograph could have benefited from including plates from the visual artists whose tableaux vivants, sculptures and paintings were seminal for Ruskin, Gregory and their circle. Apart from that, this outstanding and extremely readable study enriches the body of research on Lady Gregory and the Revival, but it also opens the door for further research on the "sister arts" (p. 121) and the influence of contemporary thinkers and philosophers in Irish and English literary criticism and pedagogy.

Sorcha De BRÚN

\section{Calling Cards: Ten Younger Irish Poets, Peter Fallon, Aifric Mac Aodha (eds.), Loughcrew, The Gallery Press - Poetry Ireland / Éigse Éireann, 2018, 112 p.}

Nuala Ní Dhomhnaill once described the act of writing poetry in Irish as an act akin to placing a baby in a basket and setting it downstream, in the hope that it would find some "iníon Fharoinn", "Pharaoh's daughter" (trans. Paul Muldoon). Dual-language anthologies, and there is now a number of them, may tell us little about the state or size of the Irish-reading public but it does perhaps show that the English-reading public for poetry in Ireland, as well as English-language Irish poets, at least regard an Ghaeilge with benevolence and some interest. 